\title{
A personal response to: Zen and the Art of Motorcycle Maintenance by Robert Pirsig
}

James Willis General Practitioner, Alton, Hampshire

\begin{abstract}
"Unless you are fond of hollering you don't make great conversations on a running cycle. Instead you spend your time being aware of things and meditating on them. On sights and sounds, on the mood of the weather and things remembered, on the machine and the countryside you're in, thinking about things at great leisure and length without being hurried and without feeling that you are losing time". (p 17)
\end{abstract}

The gentle voice is incredibly familiar, heard now for the third time, a voice that seems to have got itself into my deepest being.

Not that I came to the book very quickly. I never do. It had all the hallmarks of a fashion, way back in the early seventies when people used to talk about it. Zen-motorcycles-ugh. All far too flowerpowery for me. But I've made up for it since.

I can't remember who persuaded me to try it, but when I eventually did I understood enough of it to want to read it again. Very carefully. In fact I highlighted great chunks of it the second time, in a rather ugly, green highlighter, and then lent the copy to somebody and never saw it again. Which is just as well, I don't think highlighter is the way to summarise an odyssey, to capture the sound of that motorcycle in the empty vastness of minor-road prairie America, or the voice of Pirsig as he quietly unfolds the many purposes of his wonderful book. His sensing of that coming storm (the returning ghost) long before the first thin line of cloud is visible on the far horizon. Long before his son, Chris, close behind him on the bike but terribly distant, senses it, or their travelling companions John and Sylvia do, up the road ahead on their expensive BMW. Of whose surface they are so proud, but of whose inner workings they have no understanding at all.

"What I would like to do now is use the time that is coming now to talk about some things that have come to mind. We're in such a hurry most of the time we never get much chance to talk. The result is a kind of endless day-to-day shallowness, a monotony that leaves a person wondering years later where all the time went and sorry that it's all gone. Now that we do have some time, and know it, I would like to use the time to talk in some depth about things that seem important." (p 17)

The first time you read the book it takes you (at least it took me) practically the whole of it to be sure that the extraneous third person he calls Phaedrus, whom he shares with us but with no one in the book (except, gradually, with Chris) is in fact himself. One track of his Odyssey is this agonised rediscov- ery of the part of his mind which, before his breakdown and his ablative ECT therapy, used to be a brilliant, radical professor of rhetoric, IQ 170, obsessed with the meaning of Quality. By which he meant the Good. By which he meant the God. By which he meant the Buddha. By which he meant the Tao.

With us as his confidant Pirsig revisits the classrooms where the epic confrontations of this Phaedrus, both student and teacher, occurred. We watch him inch open the long-locked lid of the box of Phaedrus's ideas. Dangerous, exciting, compelling ideas which once convinced him that the world was insane; and which convinced the world he was. Together we excavate for the buried foundations of his certainty that ancient Greek philosophers took a desperately important wrong turning when they swept aside the softer teachings of the Sophists they replaced.

"Truth won, the Good lost, and that is why today we have so little difficulty accepting the reality of truth and so much difficulty accepting the reality of Quality, even though there is no more agreement in one area than in the other." ( $\mathrm{p} 375$ )

The tragedy is that Pirsig wrote his book in the seventies believing, and rightly, that Phaedrus's ideas would fall on more receptive minds than they had in the fifties when their author first tried to propound them. He expected this trend towards enlightenment would continue, but of course we know that it hasn't. In the seventies it would have been thought madness to suggest that medical practice could be defined by rigid rules. Today it is our tragedy to live at a time when this bizarre idea is the orthodoxy, held with frightening certainty by those on high, and it is to think otherwise that is now thought mad, and those who do so are rejected as completely as Phaedrus ever was.

Of course, the beauty of the book is its balance, caught so neatly in its famous title. The art of motorcycle maintenance. What could be more technical than a motorcycle? If there is art here, surely it must be everywhere! Q, as they say, ED. 
So, Pirsig makes it clear beyond the slightest doubt that he is a superb technician; that is what makes it so difficult to ignore what he says about abstract things. It is transparently obvious that he knows what he is talking about when he describes how to cope with the setback of assembling an engine in the wrong order and then having to take it apart again. Similarly he knows exactly why a shim cut from an aluminium beer-can will make a perfect solution to the slight looseness of John's handlebars, although John can't accept such defilement of his precious BMW and prefers to leave the handlebars loose, perhaps for ever. "I was seeing what the shim meant." Pirsig patiently explains. "He was seeing what the shim was." (p 60)

In just the same way he obviously knows what he is doing when he hikes into the mountains with his son. He had spent a lot of time hiking in the mountains in his former self. To Chris's disgust he ducks the summit this time, partly because of increasing rock-falls but partly because he has reached a peak in his own mind, which is what he really set out to achieve. But as they descend, far from any track, a step at a time, hacking through dense woods with a machete, we have no doubt he is going to find his way back to the road.

In just the same way Pirsig knows what he is talking about on the abstract things, the philosophy stuff. The irony of the book is that we know, perhaps more than he does himself, that the quiet voice we are listening to comes straight from that brilliant mind and not just from a humble technical author, which is what he says he is now content to be:

"What you've got here, really, are two realities, one of immediate artistic appearance and one of underlying scientific explanation, and they don't match and they don't fit and they don't really have much of anything to do with one another. That's quite a situation. You might say there's a little problem here." (p 63)

The relevance of this book to our present-day situation seems to me impossible to exaggerate. This is a view with which contemporary critics concurred. To pick out isolated extracts is my job, but of course it's a distortion. None the less, try this for size:

"It's the style that gets you; technological ugliness syruped over with romantic phoniness in an attempt to produce beauty and profit by people who, though stylish, don't know where to star because no one has ever told them there's such a thing as Quality in this world and it's real, not style. Quality isn't something you lay on top of objects like tinsel on a Christmas tree. Real Quality must be the source of the subjects and objects, the cone from which the tree must start ...” (p 296)

Or this:

"My personal feeling is that this is how any further improvement of the world will be done: by individuals making Quality decisions and that's all. God, I don't want to have any more enthusiasm for big programs full of social planning for big masses of people that leave individual Quality out. These can be left alone for a while. There's a place for them but they've got to be built on a foundation of Quality within the individuals involved. We've had that individual Quality in the past, exploited it as a natural resource without knowing it, and now it's just about depleted. Everyone's just about out of gumption. And I think it's about time to return to the rebuilding of this American resourceindividual worth. There are political reactionaries who've been saying something close to this for years. I'm not one of them, but to the extent they're talking about real individual worth and not just an excuse for giving more money to the rich, they're right. We do need a return to individual integrity, self-reliance and old-fashioned gumption. We really do. I hope that in this Chautauqua some directions have been pointed to.” (p 362)

Chris likes ghost stories and his father says he can't remember any, "Go to sleep". But he knows really he is writing about ghosts; this ghost of his former self; the ghosts of the Sophist philosophers; the ghost in the machine, that perhaps most of all. And he is writing about journeys; this journey across half of America, which I have on this third reading marked with a trail of "push-pins" on my Encarta atlas (at last finding something the computer map does well); then this journey of discovery of his former self, then this journey in his relationship with his son; then this journey towards greater understanding of reality-which is the mysterious purpose of our lives.

The scene which from my first reading always seemed the centre of the book comes surprisingly near the end (pages 359-60 of my 416-page edition). It is the one where a taciturn and monosyllabic mechanic in Grants Pass, Oregon, barely 70 miles from the Pacific coast, performs what seemed to be an impossible welding job on a torn metal chain-guard after a replacement had been found to be unobtainable. The description of that lone man's exquisite and totally unselfconscious artistry is beautifully done and impossible to render out of context. You need to have travelled those weary roads.

"Can I have a motorcycle when I get old enough?", says Chris, on the penultimate page.

"If you take care of it."

"What do you have to do?"

"Lots of things. You've been watching me."

"Will you show me all of them?"

"Sure."

"Is it hard?"

"Not if you have the right attitudes. It's having the right attitudes that's hard."

Pirsig convinces, utterly, that in motorcycle maintenance, of all superbly chosen examples, the art is more fundamental than the science. It's having the right attitudes that matters. So, we must ask ourselves, how much more must this apply to medi- 
cine! How could we ever have been so blind as to think otherwise! Perhaps our greatest contemporary folly has been to forget to work on those attitudes. Perhaps a journal of medical humanities is a big step in the right direction. I certainly hope so.

Back, then, one and a half thousand miles to North Dakota and to the middle of chapter Three. The two bikes have exchanged a signal and decided to run for it to escape that looming storm he had seen coming two chapters earlier. Pirsig describes the way they pick up speed. Seventy . . . eighty . . . eighty-five ... The road verge blurring, going out of focus. Ninety miles an hour. The machine running superbly. That tight, "packed", high-rev sound that shows the engine he maintains so lovingly is perfectly tuned. And then:

"A flash and Ka-wham! Of thunder, one right on top of the other. That shook me, and Chris has got his head against my back. A few warning drops of rain ... at this speed they are like needles . A second flash-WHAM and everything brilliant ... and then in the brilliance of the next flash that farmhouse ... that windmill ... oh, my God, he's been here! . . . throttle off . . . this is his road ... a fence and trees .... and the speed drops to seventy, then sixty, then fifty-five and I hold it there." (p 38)

"Why did you slow down, Dad?" Says Chris that evening, when they are safe and dry. "Sylvia said she thought you saw a ghost."

He did see a ghost; Phaedrus had arrived in the story.

Fames Willis is a General Practitioner in Alton, Hampshire. 